\title{
THE USE OF ONLINE WASTE MANAGEMENT SYSTEM IN BANK SAMPAH INDUK BANTUL
}

\author{
Sari Wulandari ${ }^{1 *}$, Putra Fajar Alam ${ }^{2)}$ \\ ${ }^{1)}$ Program Studi Teknik Industri, Fakultas Rekayasa IndustriUniversitas Telkom \\ ${ }^{2)}$ Program Studi Sistem Informasi, Fakultas Rekayasa Industri Universitas Telkom \\ *Email: sariwulandariit@telkomuniversity.ac.id
}

\begin{abstract}
In developing countries, including Indonesia, household waste is a multidimensional problem, namely that in its completion it involves many aspects so that the application of community-based solutions is needed. Waste banks are one solution to reduce household waste. A waste bank is a community-based waste management system that actively engages the community. The surrounding neighborhood can exchange trash into other forms that have economic value. The waste bank that is a model for other waste banks in Indonesia is the Bank Sampah Induk Bantul, which was established in 2008 and has used an online-based waste management system as of 2015. An online-based waste management system is one of the efforts to facilitate the activities of managers and customers ofwaste bank. However, its use in Bank Sampah Induk Bantulis stilllimited. Therefore, a preliminary study was conducted to determine the extent to which the online waste management system is used, so that appropriate actions can be taken to increase the use of the online system. This study uses a qualitative approach, namely field observations, semi-structured interviews and informal discussions. The results of this study indicate that the use of onlinebased waste management systems is not optimal because the online system does not accommodate the activities and problem solving faced by the Waste Bank. Besides, in the online-based waste management system, there are several features needed by the Waste Bank, but their use is limited due to technology acceptance from the Waste Bank management which is still relatively low.
\end{abstract}

Keywords: Waste Bank; Waste Management System; Bank Sampah Induk Bantul.

\section{PENDAHULUAN}

Sampah rumah tangga terutama sampah solid merupakan masalah multidimensional yang terjadi pada negara berkembang (Indrianti, 2016). Salah satu upaya yang telah dilakukan untuk mengurangi sampah dan memperbaiki kebersihan lingkungan adalah dengan menerapkan sistem bank sampah. Bank sampah merupakan sistem pengelolaan sampah berbasis komunitas yang memungkinkan masyarakat secara aktif mengelola sampah di lingkungannya (Wijayanti \& Suryani,
2015). (Singhirunnusorn, Donlakorn, \& Kaewhanin, 2012) dalam penelitiannya menemukan bahwa penerapan sistem bank sampah secara signifikan mengurangi tumpukan sampah, membantu komunitas dalam mengelola sampah kering dengan baik, membantu mengatasi masalah kesehatan, sertamenghasilkan lingkungan hidup yang lebih baik. Menurut (Asteria \& Heruman, 2016), bank sampah mengajarkan masyarakat untuk melakukan kegiatan pemilahan sampah, menumbuhkan kesadaran masyarakat agar mengolah sampah secara bijak 
sehingga dapat mengurangi sampah yang diangkut ke TPA. Selain itu, bank sampah memungkinkan masyarakat sekitar untuk menukar sampah rumah tangga mereka ke dalam bentuk uang atau bentuk lainnya seperti sembako, pulsa telepon atau pulsa listrik. Sampah yang diterima kemudian disalurkan dan dijual kepada pengepul dan pengrajin lokal untuk diolah menjadi barang yang memiliki nilai jual. Oleh karena itu, keberadaan bank sampah juga memberikan keuntungan eknomis kepada masyarakat sekitar seperti menciptakan lapangan pekerjaan, sumber pendapatan tambahan, sementara pemerintah kota dapat mengurangi biaya penanganan dan pembuangan sampah untuk daerah setempat (Singhirunnusorn, Donlakorn, \& Kaewhanin, 2012).

Ide "menabung sampah" dengan sistem Bank Sampah pertama kali diperkenalkan di Thailand pada tahun 2006 (Wijayanti \& Suryani, 2015). Di Indonesia, Bank Sampah Induk Bantul merupakan pionir didirikannya Bank Sampah. Bank Sampah Induk Bantul didirikan pada tahun 2007 oleh Bambang Suwerda, oleh karenanya dapat diketahui bahwa Bank Sampah Induk Bantul sudah berdiri kurang lebih selama 11 tahun. Bank Sampah Induk Bantul merupakan bank sampah induk yang dijadikan sebagai percontohan untuk bank sampah di Indonesia bahkan luar negeri (Kusmargana, 2018). Bank Sampah Induk Bantul dikelola bersama dengan Badan Lingkungan Hidup (BLH) Kabupaten Bantul, Yogyakarta didirikan sebagai respon terhadap permasalahan sampah di Provinsi Yogyakarta. Penelitian yang dilakukan (Sudibyo, Pradana, Budiman, \& Budhijanto, 2017)menunjukkan bahwa di sampah di Provinsi Yogyakarta mencapai 470 ton setiap harinya dengan kenaikan $8 \%$ setiap tahunnya. Selain itu, menurut Kepala Dinas Lingkungan Hidup (DLH),
Yogyakarta, (Rusqiyati, 2018), mengatakan bahwa setidaknya diperlukan jumlah nasabah sebanyak dua per tiga dari total bank sampah keseluruhan agar operasional Bank Sampah dapat berjalan dengan baik. Pada tahun 2016, terdapat 131 bank sampah, 10 diantaranya tidak aktif atau kegiatannya tidak produktif (Sidik, 2016), sedangkan pada tahun 2018, menurut data pada komunitas Jejaring Pengelola Sampah Mandiri ada sebanyak 64 bank sampah yang aktif dengan jumlah nasabah sebanyak 2.496 . Berdasarkan data tersebut dapat diketahui bahwa terdapat penurunan jumlah bank sampah yang aktif dan ratarata bank sampah hanya memiliki 39 nasabah aktif.Di sisi lain, masyarakat sekitar Bantul baik sebagai pengelola dan nasabah merasakan manfaat yang sangat besar dari keberadaan bank sampah. Bank Sampah Induk Bantul memberdayakan ibu rumah tangga dan anak muda sekitar Bantul untuk mengelola sampah menjadi produk akhir yang dapat dijual dan menghasilkan uang. Uang tersebut kemudian akan kembali kepada nasabah, sehingga nasabah pun mendapatkan pemasukan tambahan untuk kebutuhan sehari-hari. Namun, ternyata masih banyak masyarakat sekitar yang belum aktif menjadi nasabah Bank Sampah. Oleh karenanya, Bank Sampah Induk Bantul berupaya untuk terus berkomitmen dalam pengelolaan sampah dan melakukan perbaikan sehingga dapat mengatasi masalah sampah dan berkontribusi terhadap peningkatan kesejahteraan masyarakat sekitar Bantul.

Berdasarkan hasil wawancara kepada Pak Bambang selaku pendiri dan pengelola Bank Sampah Induk Bantul diketahui bahwa terdapat beberapa kendala dalam mengelola Bank Sampah Induk Bantul diantaranya pengelolaan data nasabah masih dilakukan secara 
manual yaitu menggunakan kertas dan buku catatan sehingga sangat rentan akan kesalahan perhitungan dan hilangnya buku nasabah, kepengurusan pengelola bank sampah seringkali berganti karena bersifat sukarela sehingga ketika terjadi pergantian kepengurusan seringkali informasi sebelumnya banyak yang hilang atau belum tersampaikan dengan baik kepada kepengurusan yang baru, serta fokus pengurus masih terbagi-bagi karena seringkali pengurus juga memiliki pekerjaan selain menjadi pengurus bank sampah. Selain itu, dari sisi nasabah juga terdapat beberapa masalah diantaranya adalah kurangnya kesadaran masyarakat untuk hidup bersih, masih banyak masyarakat yang belum membiasakan menabung sampah, dan mayoritas nasabah merupakan orang tua sedangkan potensi nasabah sangat besar untuk masyarakat dengan usia muda.Untuk menjawab permasalahan tersebut, aplikasi pengelolaan sampah berbasis online dapat dijadikan sebagai solusi. Aplikasi pengelolaan sampah berbasis online merupakan aplikasi pengelolaan bank sampah dan nasabahnya untuk melakukan proses tabung sampah. Di Surabaya, bahkan diadakan kompetisi pembuatan aplikasi Bank Sampah sebagai pendekatan inovatif untuk meningkatkan penyerapan proyek Bank Sampah (Wijayanti \& Suryani, 2015). Bank Sampah Induk Bantul telah menggunakan aplikasi tersebut dalam pengelolaan bank sampah sejak tahun 2015. Namun penggunaannya oleh nasabah masih dapat dikatakan rendah, nasabah merasa lebih nyaman menabung secara offline. Oleh karena itu, untuk meningkatkan penggunaan aplikasi online pada Bank Sampah Induk Bantul diperlukan studi pendahuluan mengenai bagaimana sistem manajemen sampah secara onlinedigunakan.

\section{METODOLOGI}

Penelitian ini menggunakan pendekatan kualitatif sebagai metode penelitian. Data diperoleh dengan menggunakan teknik pengambilan data semi terstruktur dan diskusi informaldengan nasabah bank sampah (sebanyak 6 responden nasabah), komunitas pengelola sampah, dan pengelola Bank Sampah yaitu Direktur (Bapak Bambang Suwerda), Sekretaris (Ibu Yunita), Koordinator Daur Ulang Plastik (Ibu Sri Hartini) dan Koordinator Kompos (Bapak Rojihan).Selain itu, dilakukan observasi lapangan terkait proses tabung sampah dari awal hingga akhir. Pada penelitian ini juga dilakukan analisis dokumen, khususnya yang berdasar padadata Komunitas Jejaring Pengelola Sampah Mandiri sebagai data pendukung penelitian. Beberapa hasil studi literatur juga dilakukan untuk mengetahui bagaimana bank sampah berkembang di Indonesia, khususnya di Bantul.

\section{HASIL DAN PEMBAHASAN}

\subsection{Profil Bank Sampah Induk Bantul 3.1.1 Kepengurusan Bank Sampah Induk Bantul}

Struktur kepengurusan Bank Sampah Induk Bantul dapat dilihat pada Gambar 1. yaitu terdiri dari 4 layer utama. Layer pertama merupakan direktur, layer kedua terdiri dari sekretaris dan bendahara, layer ketiga terdiri dari koordinator pendamping lapangan dan teller bank sampah, layer keempat merupakan koordinator daur ulang styrofoam, koordinator daur ulang plastik, koordinator kompos, petugas pemilah sampah, petugas kebersihan dan petugas pengangkut sampah. Pada layer empat tersebut, masing-masing posisi diisi oleh 1 orang petugas.Pengurus bank sampah yang kemudian disebut sebagai 
pengelola bank sampah merupakan mengelola bank sampah sebagai sukarelawan yang menjadikan tugas pekerjaan sampingan.

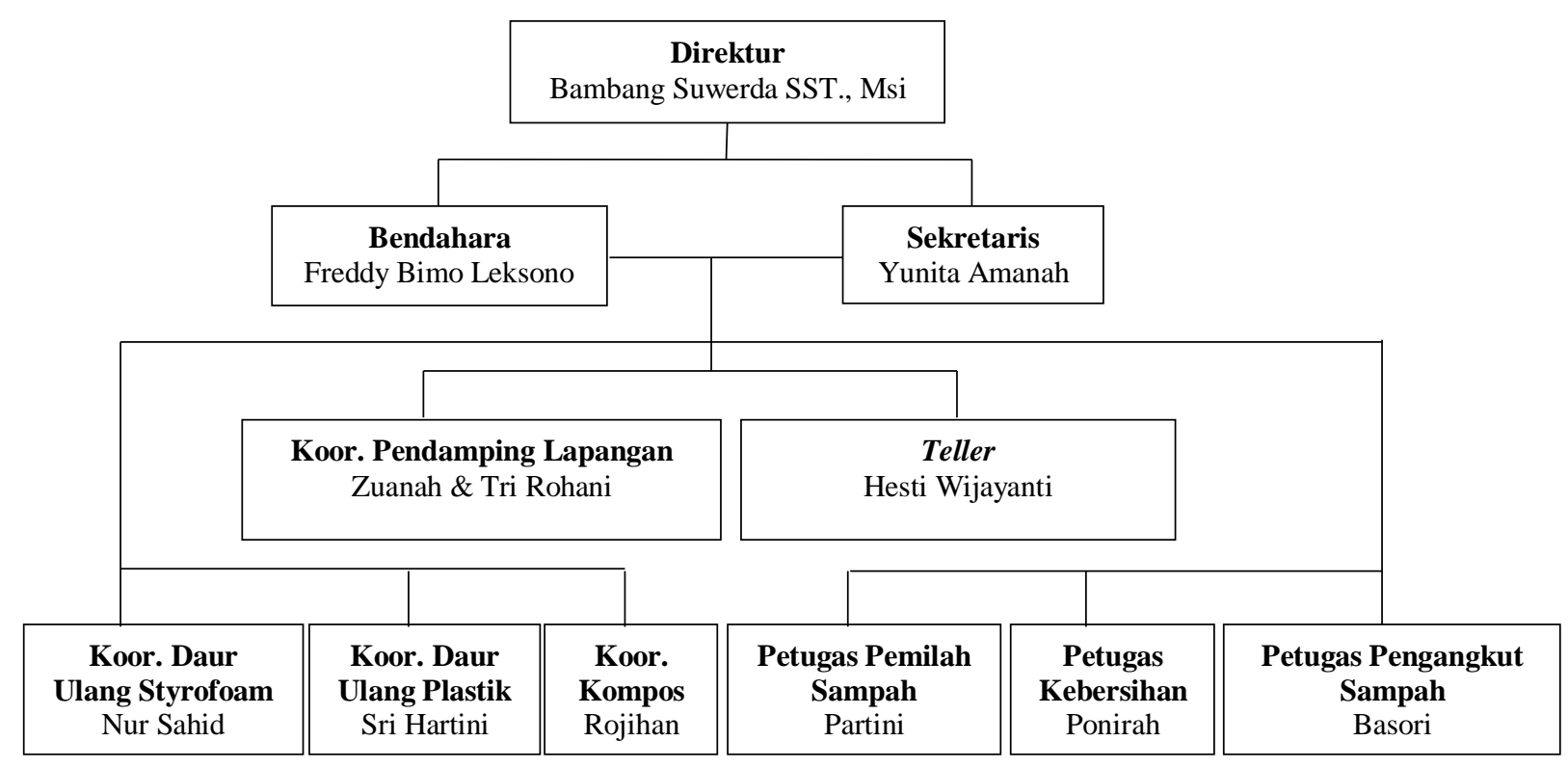

Gambar 1.

Struktur Kepengurusan Bank Sampah Induk Bantul

Bank Sampah Induk Bantul sudah beberapa kali mengalami perubahan kepengurusan dan belum ada media atau aktivitas transfer pengetahuan dari kepengurusan sebelumnya. Selain itu, pembagian tugas pengelola bank sampah sudah jelas namun pada pelaksanaannya semua pengelola melakukan semua tugas atau fungsi yang dibutuhkan pada bank sampah. Hal tersebut menyebabkan pengelola tidak fokus pada satu pekerjaan saja. Tidak adanya komitmen dan arahan yang kuat dari pihak direktur maupun pengelola dalam melakukan digitalisasi proses pengelolaan bank sampah, menghambat bank sampah untuk menggunakan aplikasi sebagai alat operasional harian bank sampah.

\subsubsection{Statistik Bank Sampah Induk Bantul}

Bank Sampah Induk Bantul merupakan bank sampah pionir di Indonesia dan menjadi percontohan bagi bank sampah lainnya untuk daerah tersebut. Oleh karenanya, kebanyakan nasabah mengetahui dan melakukan proses tabung sampah pada bank sampah tersebut. Bank Sampah Induk Bantul membawahi 60 bank sampah di daerah Bantul.

Tabel 1. Statistik Bank Sampah Induk

Bantul Tahun 2015 - 2017

\begin{tabular}{|l|l|l|l|}
\hline Keterangan & $\begin{array}{l}\text { Tahun } \\
\mathbf{2 0 1 5}\end{array}$ & $\begin{array}{l}\text { Tahun } \\
\mathbf{2 0 1 6}\end{array}$ & $\begin{array}{l}\text { Tahun } \\
\mathbf{2 0 1 7}\end{array}$ \\
\hline $\begin{array}{l}\text { Tonase } \\
\text { Sampah }\end{array}$ & $\begin{array}{l}5,66 \\
\text { ton }\end{array}$ & $\begin{array}{l}55,63 \\
\text { ton }\end{array}$ & $\begin{array}{l}70,42 \\
\text { ton }\end{array}$ \\
\hline $\begin{array}{l}\text { Saldo } \\
\text { Tabungan }\end{array}$ & $\begin{array}{l}67,22 \\
\text { juta }\end{array}$ & $\begin{array}{l}117,14 \\
\text { juta }\end{array}$ & $\begin{array}{l}208,03 \\
\text { juta }\end{array}$ \\
\hline $\begin{array}{l}\text { Jumlah } \\
\text { Transaksi }\end{array}$ & 1.453 & 10.764 & 7.412 \\
\hline $\begin{array}{l}\text { Nasabah } \\
\text { Aktif }\end{array}$ & 1.070 & 4.451 & 2.949 \\
\hline
\end{tabular}

Data pada Tabel 1. merupakan data profil Bank Sampah Induk Bantul terhitung dari semenjak Bank Sampah Induk Bantul menggunakan sistem 
manajemen sampah berbasis online. Berdasarkan data pada Tabel 1.tersebut diketahui bahwa terjadi peningkatan jumlah tonase sampah yang sangat signifikan pada tahun 2016 yaitu dari 5,66 ton pada tahun 2015 menjadi 55,63 ton. Penelitian yang dilakukan oleh (Soni, Patil, \& Argade, 2016) menyatakan bahwa dibandingkan melihat sampah anorganik sebagai sampah yang tidak bermanfaat, akan lebih baik melihatnya sebagai suatu sumber energi, yang jika dikelola dengan baik berpotensi untuk diolah menjadi biodiesel, bio CNC, minyak etanol dan pupuk cair. Hal ini tentu membutuhkan proses pendataan yang baik melalui sistem manajemen sampah berbasis online. Selain itu, menurut (Sahwan, 2004), jika menerapkan konsep TPA terpadu, dari setiap 100 ton sampah dengan komposisi 70 ton sampah organik dan 30 ton sampah anorganik dapat menghasilkan 17 ton kompos dan bahan daur ulang.

Selain itu, pada tahun 2016, saldo tabungannya meningkat hampir 2 kali lipat dari tahun sebelumnya. Kondisi tersebut juga ditunjukan dari besarnya jumlah transaksi pada tahun 2016 yaitu sebanyak 10.764 transaksi. Pada data tersebut juga dapat diketahui bahwa terjadi peningkatan nasabah aktif pada tahun 2016 namun jumlahnya menurun pada tahun 2017, begitu pula dengan jumlah transaksinya. Walaupun demikian, pada tahun 2017 jumlah tonase sampah, saldo tabungan menunjukan peningkatan dari tahun sebelumnya.Tahun 2015 merupakan tahun pertama Bank Sampah Induk Bantul menggunakan sistem manajemen sampah berbasisonline. Jika data tahun 2016 dan 2017 dibandingkan dengan tahun 2015, dapat diketahui bahwa aktivitas tahun 2015 merupakan aktivitas terendah semenjak sistem online digunakan. Hal ini dikarenakan pada tahun 2015, bank sampah masih melakukan penyesuaian dan beberapa data belum terdokumentasikan dengan baik. Berdasarkan data tersebut, maka dapat disimpulkan bahwa penggunaan sistem manajemen sampah berbasisonline membantu proses pendataan dengan baik dan membantu bank sampah dalam meningkatkan awareness masyarakat akan kegiatan penabungan sampah yaitu terlihat dari peningkatan tonase sampah di setiap tahunnya. Berikut Gambar 2. Hingga Gambar 4. data setoran sampah sepanjang per tahun 2015 - 2017.

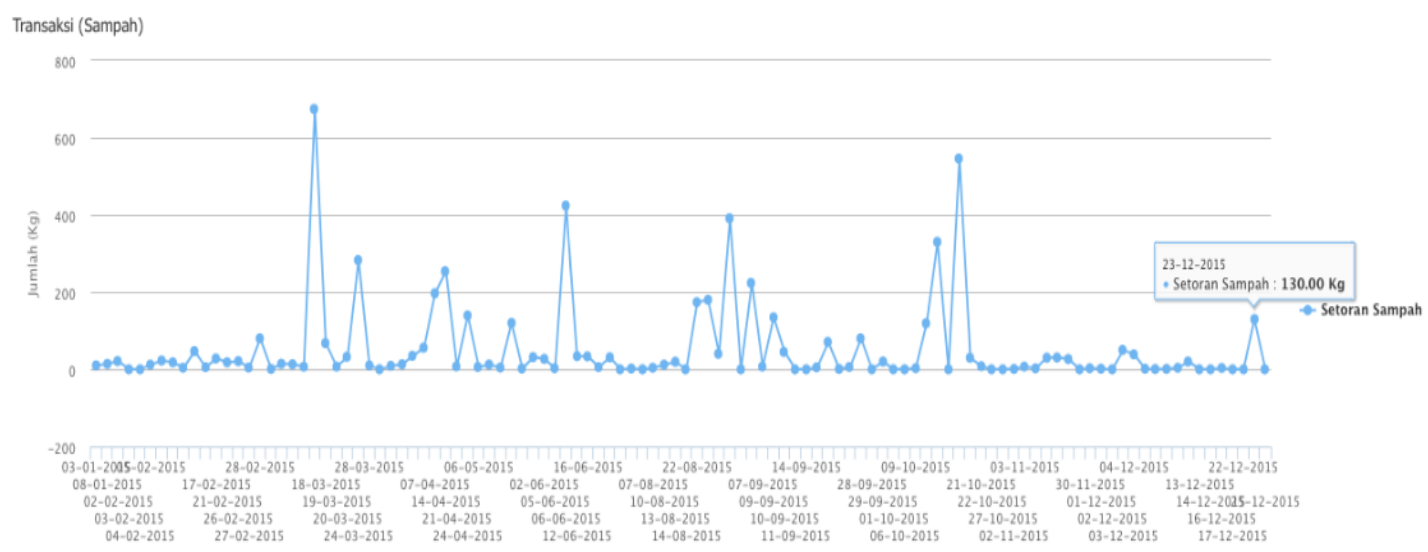

Gambar 2.

Setoran Sampah Tahun 2015 


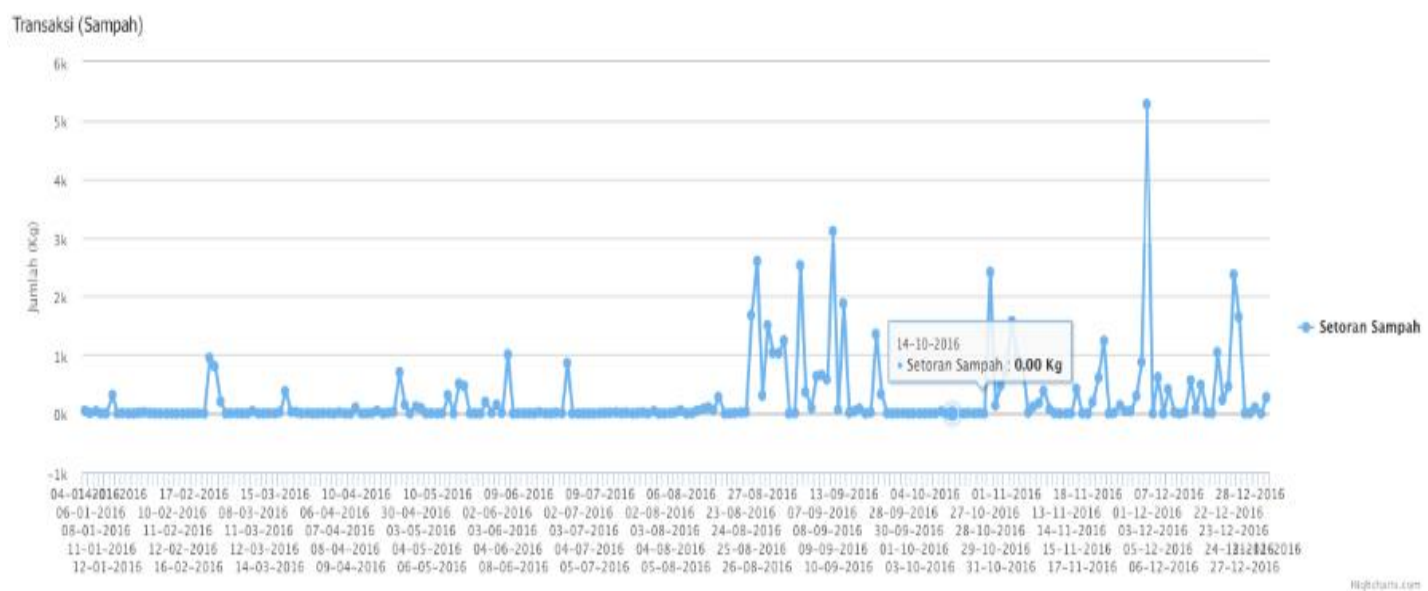

Gambar 3.

Setoran Sampah Tahun 2016

Transaksi (Sampah)

$20 \mathrm{k}$

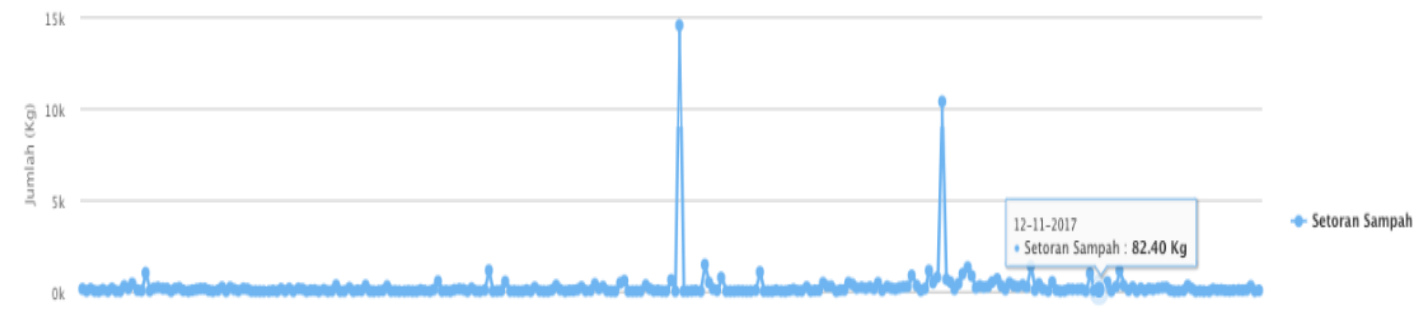

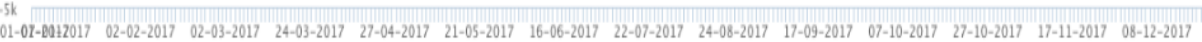

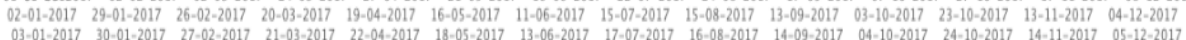

$\begin{array}{llllllllllllll}03-01-2017 & 30-01-2017 & 27-02-2017 & 21-03-2017 & 22-04-2017 & 18-05-2017 & 13-06-2017 & 17-07-2017 & 16-08-2017 & 14-09-2017 & 04-10-2017 & 24-10-2017 & 14-11-2017 & 05-12-2017 \\ 05-01-2017 & 31-01-2017 & 28-02-2017 & 22-03-2017 & 25-04-2017 & 19-05-2017 & 14-06-2017 & 18-07-2017 & 17-08-2017 & 15-09-2017 & 05-10-2017 & 25-10-2017 & 15-11-2017 & 06-12-20131-12-2017\end{array}$

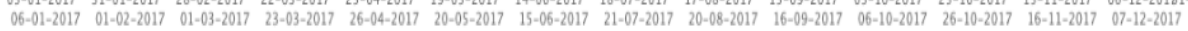

Gambar 4.

Setoran Sampah Tahun 2017

3.1.3 Kendala Operasional Bank Sampah Berdasarkan

Tahapan Proses Tabung Sampah

Berdasarkan hasil observasi proses tabung sampah dan wawancara informal terhadap pengelola bank sampah serta beberapa nasabah Bank
Sampah Induk Bantul (6 nasabah), dapat diidentifikasi potensi masalah baik dari sisi bank sampah maupun nasabah bank dalam proses tabung sampah. Berikut adalah hasil pemetaan potensi masalah berdasarkan kendala yang dialami bank sampah dan nasabah bank.

Tabel 2. Pemetaan Kendala Berdasarkan Tahapan Proses Tabung Sampah

\begin{tabular}{|l|l|l|l|}
\hline No. & Tahapan Proses & Kendala Bank Sampah & Kendala Nasabah Bank \\
\hline 1 & Pemilahan & Tenaga pemilah sangat minim & $\begin{array}{l}\text { Nasabah enggan } \\
\text { melakukan pemilahan } \\
\text { karena tidak nyaman } \\
\text { dengan bau dan kondisi } \\
\text { sampah yang kotor }\end{array}$ \\
\cline { 3 - 4 } & & $\begin{array}{l}\text { Tenaga pemilah tidak selalu } \\
\text { tersedia }\end{array}$ & \\
\hline
\end{tabular}




\begin{tabular}{|c|c|c|c|}
\hline No. & Tahapan Proses & Kendala Bank Sampah & Kendala Nasabah Bank \\
\hline & & & $\begin{array}{l}\text { Minimnya pengetahuan } \\
\text { nasabah mengenai kategori } \\
\text { sampah yang dapat dijual }\end{array}$ \\
\hline & & & $\begin{array}{l}\text { Tidak tersedia cukup } \\
\text { informasi mengenai } \\
\text { kategori sampah }\end{array}$ \\
\hline \multirow[t]{5}{*}{2} & \multirow[t]{5}{*}{ Penyetoran } & \multirow[t]{2}{*}{$\begin{array}{l}\text { Bank sampah tidak buka setiap } \\
\text { waktu (hanya hari-hari tertentu) }\end{array}$} & $\begin{array}{l}\text { Lokasi rumah yang jauh } \\
\text { dengan bank sampah }\end{array}$ \\
\hline & & & \multirow{2}{*}{$\begin{array}{l}\text { Banyaknya sampah yang } \\
\text { harus dibawa }\end{array}$} \\
\hline & & \multirow{2}{*}{$\begin{array}{l}\text { Tenaga penjemput sampah tidak } \\
\text { selalu tersedia }\end{array}$} & \\
\hline & & & \multirow{2}{*}{$\begin{array}{l}\text { Beberapa nasabah bahkan } \\
\text { menitipkan sampahnya } \\
\text { kepada nasabah lain yang } \\
\text { hendak melakukan setor } \\
\text { sampah }\end{array}$} \\
\hline & & $\begin{array}{l}\text { Tidak semua jenis / kategori } \\
\text { sampah dapat ditampung pada } \\
\text { bank sampah }\end{array}$ & \\
\hline \multirow[t]{5}{*}{3} & \multirow[t]{5}{*}{ Pencatatan } & \multirow{3}{*}{$\begin{array}{l}\text { Aktivitas pencatatan berulang } \\
\text { pada rekap saldo nasabah } \\
\text { (buku induk tabungan dan } \\
\text { pencatatan pada komputer) }\end{array}$} & $\begin{array}{l}\text { Buku tabungan seringkali } \\
\text { tertinggal atau terselip }\end{array}$ \\
\hline & & & $\begin{array}{l}\text { Nasabah lupa menaruh } \\
\text { buku tabungan }\end{array}$ \\
\hline & & & \multirow{2}{*}{$\begin{array}{l}\text { Ketika buku tabungan } \\
\text { hilang, maka } \\
\text { membutuhkan waktu yang } \\
\text { cukup lama untuk melihat } \\
\text { posisi terakhir rekening }\end{array}$} \\
\hline & & \multirow[t]{2}{*}{$\begin{array}{l}\text { Pencatatan dilakukan manual } \\
\text { dengan menggunakan } 2 \text { slip } \\
\text { dokumen }\end{array}$} & \\
\hline & & & $\begin{array}{l}\text { Nasabah menghitung } \\
\text { secara manual saldo } \\
\text { mereka }\end{array}$ \\
\hline \multirow[t]{2}{*}{4} & \multirow[t]{2}{*}{ Penyimpanan } & $\begin{array}{l}\text { Keterbatasan lahan untuk } \\
\text { menampung sampah yang } \\
\text { diterima dan belum terjual atau } \\
\text { terolah }\end{array}$ & \multirow[t]{2}{*}{$\begin{array}{l}\text { Nasabah perlu } \\
\text { menyediakan kantong } \\
\text { khusus untuk menyimpan } \\
\text { sampah terpilah dan tidak } \\
\text { semua nasabah siap }\end{array}$} \\
\hline & & $\begin{array}{l}\text { Sampah yang bau atau belum } \\
\text { terpilah dengan baik dapat } \\
\text { mengganggu, karena lokasi } \\
\text { yang dekat dengan pemukiman } \\
\text { warga }\end{array}$ & \\
\hline \multirow[t]{3}{*}{5} & \multirow[t]{3}{*}{$\begin{array}{l}\text { Penjualan sampah - } \\
\text { Pengepul }\end{array}$} & $\begin{array}{l}\text { Mitra pengepul terbatas hanya } 3 \\
-4 \text { pengepul }\end{array}$ & \multirow{3}{*}{$\begin{array}{l}\text { *tidak berhubungan } \\
\text { dengan pengepul } \\
\text { *Bagi hasil : } 75 \% \text { untuk } \\
\text { nasabah dan } 25 \% \text { untuk } \\
\text { bank sampah }\end{array}$} \\
\hline & & $\begin{array}{l}\text { Harga tergantung pada } \\
\text { penawaran pengepul }\end{array}$ & \\
\hline & & $\begin{array}{l}\text { Pengepul hanya menerima } \\
\text { beberapa jenis sampah saja }\end{array}$ & \\
\hline \multirow[t]{3}{*}{6} & \multirow[t]{3}{*}{ Pengolahan sampah } & $\begin{array}{l}\text { Keterbatasan variasi olahan } \\
\text { sampah }\end{array}$ & \multirow[t]{3}{*}{$\begin{array}{l}\text { *tidak berhubungan } \\
\text { dengan pengolah sampah }\end{array}$} \\
\hline & & $\begin{array}{l}\text { Kualitas olahan sampah yang } \\
\text { sangat bervariasi - tergantung } \\
\text { pada kondisi sampah }\end{array}$ & \\
\hline & & $\begin{array}{l}\text { Minimnya alat bantu pengolah } \\
\text { sampah }\end{array}$ & \\
\hline
\end{tabular}




\begin{tabular}{|c|c|c|c|}
\hline No. & Tahapan Proses & Kendala Bank Sampah & Kendala Nasabah Bank \\
\hline & & $\begin{array}{l}\text { Terdapat potensi pengolahan } \\
\text { sampah residu namun masih } \\
\text { sedikit orang yang bersedia } \\
\text { mengolahnya }\end{array}$ & \\
\hline & & $\begin{array}{l}\text { Keterbatasan tenaga pengolah } \\
\text { sampah-akses komunitas } \\
\text { pengolah sampah. }\end{array}$ & \\
\hline \multirow[t]{4}{*}{7} & \multirow[t]{4}{*}{$\begin{array}{l}\text { Penjualan sampah - olahan } \\
\text { sampah }\end{array}$} & $\begin{array}{l}\text { Produk olahan sampah hanya } \\
\text { dipajang pada etalase bank } \\
\text { sampah }\end{array}$ & \multirow[t]{4}{*}{$\begin{array}{l}\text { *Nasabah mendapatkan } \\
10 \% \text { hasil penjualan } \\
\text { olahan sampah }\end{array}$} \\
\hline & & Penjualan cenderung rendah & \\
\hline & & $\begin{array}{l}\text { Belum bisa menerima pesanan } \\
\text { dalam jumlah besar }\end{array}$ & \\
\hline & & $\begin{array}{l}\text { Produk olahan sampah yang } \\
\text { akan diekspor belum konsisten } \\
\text { memenuhi standar minimal } \\
\text { mutu }\end{array}$ & \\
\hline \multirow[t]{3}{*}{8} & \multirow[t]{3}{*}{ Pengambilan saldo } & $\begin{array}{l}\text { Stok penukaran terbatas (tidak } \\
\text { selalu tersedia) }\end{array}$ & \multirow{2}{*}{$\begin{array}{l}\text { Nasabah harus datang } \\
\text { langsung untuk mengambil } \\
\text { hasil konversi rekening } \\
\text { (Jika stok yang tersedia } \\
\text { adalah barang), beberapa } \\
\text { nasabah keberatan, karena } \\
\text { jaraknya yang jauh }\end{array}$} \\
\hline & & \multirow[t]{2}{*}{$\begin{array}{l}\text { Item barang penukaran sampah } \\
\text { diantaranya pulsa, sembako, alat } \\
\text { elektronik }\end{array}$} & \\
\hline & & & $\begin{array}{l}\text { Barang yang dapat } \\
\text { ditukarkan terkadang tidak } \\
\text { sesuai dengan keinginan } \\
\text { nasabah (tergantung pada } \\
\text { ketersediaan barang yang } \\
\text { ada) }\end{array}$ \\
\hline
\end{tabular}

Berdasarkan Tabel 2. dapat diketahui kendala yang dialami pengelola dan nasabah bank sampah berdasarkan proses tahapan tabung sampah. Adapun peluang perbaikan atau penambahan fitur pada sistem manajemen sampah berbasis online berdasarkan tahapan proses tabung sampah adalah sebagai berikut :

1. Pemilahan - Pada tahapan ini kendala nasabah adalah terbatasnya pengetahuan nasabah mengenai kategorisasi sampah yang dapat diterima bank sampah. Menurut (Murdiman, Mahendra, \& Adhika, 2017), proses optimalisasi sampah yang sudah dipilah melalui pengangkutan swadaya dan penyediaan sarana angkut penting untuk dilakukan agar sampah yang sudah dipilah tidak dicampur kembali. Sistem manajemen sampah berbasisonline sudah memberikan fitur informasi kategori sampah yang dapat digunakan oleh nasabah sebagai panduan dalam memilah sampah, hanya saja nasabah belum memanfaatkan fitur tersebut dikarenakan adanya perbedaan informasi kategorisasi sampah pada sistem online dan offline pada bank sampah. Sebaiknya sistem online dapat mengakomodasi penyesuaian kategorisasi sampah untuk setiap bank sampah melalui akun pengelola bank sampah dan menyediakan informasi visual maupun bergerak dalam bentuk 
video sebagai media yang dapat mempermudah nasabah untuk mempelajari kategorisasi.

2. Penyetoran - Pada tahapan ini, kendala yang perlu diperhatikan adalah keterbatasan tenaga penjemput sampah. Sistem onlinetelah mengakomodasi fitur jemput sampah, namun fitur perlu dikembangkan kembali yaitu memberikan akses lebih luas kepada tenaga penjemput sampah pada bank sampah lainnya yang tersedia, sehingga dapat meningkatkan peluang ketersediaan tenaga penjemput sampah ketika ada permintaan.

3. Pencatatan - Pada tahapan ini ditemukan kegiatan pendataan yang berulang dan dapat dieliminasi melalui sistem manajemen sampah berbasis online. Kendala ini dapat diatasi dengan memberlakukan kebijakan yang dapat membiasakan pengelola maupun nasabah untuk menggunakan sistem onlinedalam pendataan (Pencatatan setor dan ambil saldo).

4. Penyimpanan - Pada tahapan ini, masalah yang perlu diperhatikan adalah ketersediaan ruang dan fasilitas penyimpanan sampah yang memadai. Namun kendala ini tidak cukup dapat diselesaikan dengan sistem online.

5. Penjualan sampahkepada pengepul - Kendala utama pada tahapan ini adalah harga jual sampah yang bergantung pada penawaran pengepul. Saat ini, Bank Sampah Induk Bantul hanya memiliki $3-4$ pengepul yang siap membeli sampah yang diterima, hal ini menyebabkan posisi tawar pengepul tinggi, sehingga harga jual pun tidak dapat ditawar terlalu tinggi. Oleh karena itu, sistem online sebaiknya dapat memberikan akses penjualan sampah ke pengepul yang berada di sekitar bank sampah.

6. Pengolahan sampah menjadi produk - Selama ini, proses pengolahan sampah dilakukan oleh masing-masing koordinator daur ulang sampah yang jumlahnya terbatas. Sistem manajemen sampah berbasis online dapat mengakselerasi aktivitas tersebut dengan memberikan askes kepada pengrajin sampah sekitar bank sampah ataupun menjalin kerjasama dengan komunitas pengrajin sampah, sehingga sampah yang diterima dapat diolah secara optimal.

7. Penjualan olahan sampah Kegiatan penjualan olahan sampah merupakan salah satu aktivitas penting, karena menurut (Ibrahim \& Nanis, 2016), pemberian insentif dan keringanan pajak untuk kegiatan daur ulang merupakan salah satu faktor yang dapat mendorong praktik terbaik dalam pengelolaan sampah. Hasil dari penjualan olahan sampah bisa menjadi salah satu insentif yang didapatkan dari proses tersebut. Sistem manajemen sampah berbasisonlinesudah

menyediakan marketplace untuk membantu penjualan produk olahan sampah, namun sampai saat ini belum ada penjualan yang dihasilkan dari marketplace tersebut. Agar penjualan produk olahan sampah (daur ulang sampah) optimal, maka produk olahan sampah dapat dijadikan 
sebagai pilihan untuk pengambilan saldo.

8. Pengambilan saldo - Fitur yang memungkinkan nasabah untuk memberikan permintaan terkait bentuk pengambilan saldo yang mereka inginkan, sehingga pihak bank sampah dapat menyediakan stok yang sesuai dengan permintaan.

\subsection{Penggunaan aplikasi pada Bank Sampah Induk Bantul}

Sosialisasi penggunaan aplikasi pengelolaan sampah online pernah dilakukan sekali kepada pengelola bank sampah dan beberapa nasabah bank. Sosialiasi tersebut memberikan arahan dan penjelasan mengenai bagaimana cara penggunaan aplikasi dari sisi pengelola yaitu menggunakan aplikasi BankSampah.id dan dari sisi nasabah yaitu menggunakan mySmash. Sebagian besar peserta sosialiasi sudah memiliki ponsel pintar atau smartphone yang sudah mendukung untuk penggunaan aplikasi, namun sangat minim pengetahuan mengenai cara mengunduh aplikasi tersebut. Feedbackpengelola bank sampah mengenai aplikasi diantaranya adalah aplikasi sudah cukup mudah untuk digunakan dan mampu menyederhanakan proses pengelolaan data, sedangkan nasabah merasa sangat terbantu dengan adanya aplikasi tersebut, kebutuhan nasabah akan informasi rekening dan bank sampah terakomodasi melalui aplikasi. Adapun fitur yang dibutuhkan nasabah diantaranya adalah layanan jemput sampah, informasi kategori sampah beserta harga, serta pengambilan saldo rekening bank sampah melalui ATM. Fitur layanan jemput sampah pada aplikasi tidak didukung dengan ketersediaan petugas

pengangkut sampah. Armada penjemputan sampah telah tersedia namun petugas seringkali tidak ada di tempat. Rendahnya penggunaan user nasabah pada sistem online, salah satunya disebabkan karena perubahan harga sampah yang tidak diperbaharui oleh pengelola bank sampah. Walaupun fitur pembaharuan data harga sampah sudah tersedia, pengelola bank sampah belum menggunakan fitur tersebut.Hal ini menyebabkan perbedaan info harga sampah pada sistem online dan bank sampah offline. Fitur lainnya yang cukup penting dan dibutuhkan nasabah adalah fitur pengambilansaldo rekening bank sampah melalui ATM pada sistem online sudah siap, namun data rekening nasabah seringkali belum diperbaharui pada sistem online. Bank sampah melakukan pembaharuan data saldo transaksi rekening pada sistem online secara kumulatif setiap $1-2$ bulan sekali bahkan tidak menentu, sehingga nasabah merasa lebih nyaman melakukan pengambilan saldo pada bank sampah secara offline. Hal ini terindikasi dari data Gambar 5. Hingga Gambar 7. mengenai data transaksi saldo pada tahun 2015 hingga 2017 yang menunjukan masih sangat rendahnya setoran dan pengambilan saldo yang tercatat pada sistem manajemen sampah berbasisonline. Namun pada Gambar 7 . yaitu gambar transaksi saldo tahun 2017, jika dibandingkan dengan data transaksi saldo pada tahun 2015 dan 2016, gambar data transaksi saldo tahun 2017 menunjukan adanya beberapa aktivitas setoran dan pengambilan saldo yang cukup di setiap harinya, sehingga dapat disimpulkan bahwa fitur setor dan tarik saldo pada sistem online mulai diterima oleh nasabah walaupun fitur tersebut belum digunakan secara optimal. 
Transaksi (Saldo)

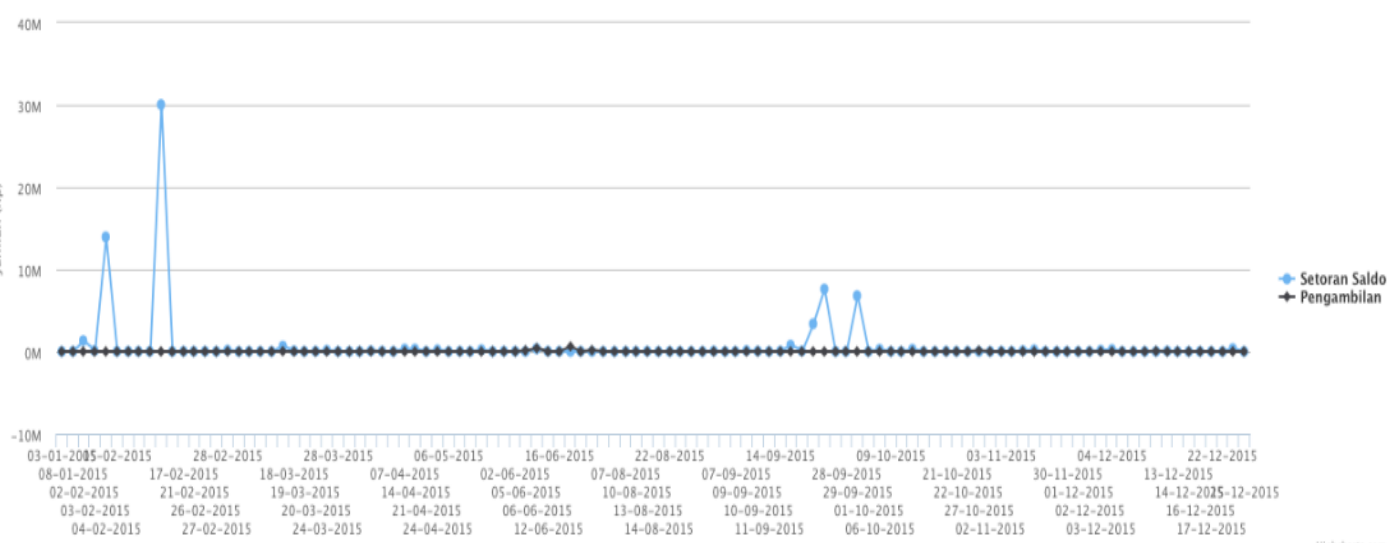

Gambar 5.

Transaksi Saldo Tahun 2015

Transaksi (Saddo)

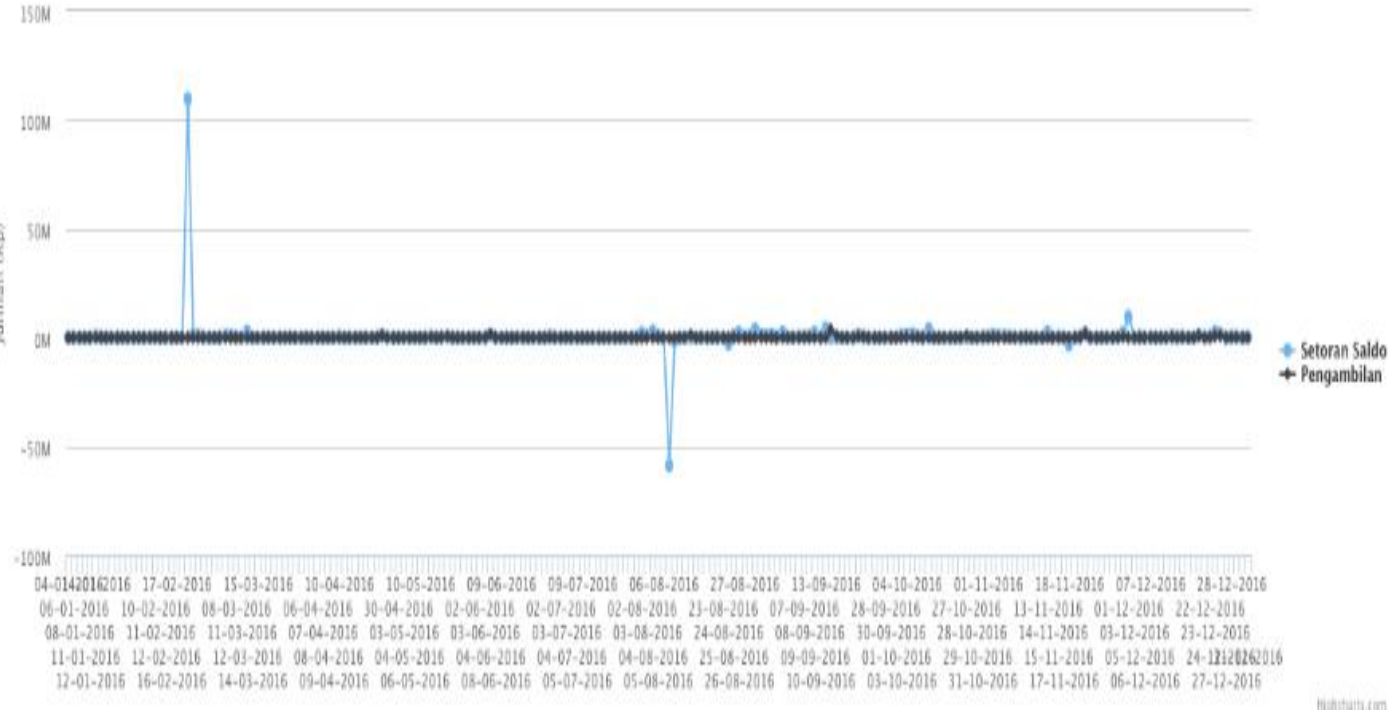

Gambar 6.

Transaksi Saldo Tahun 2016

Transaksi (Saldo)

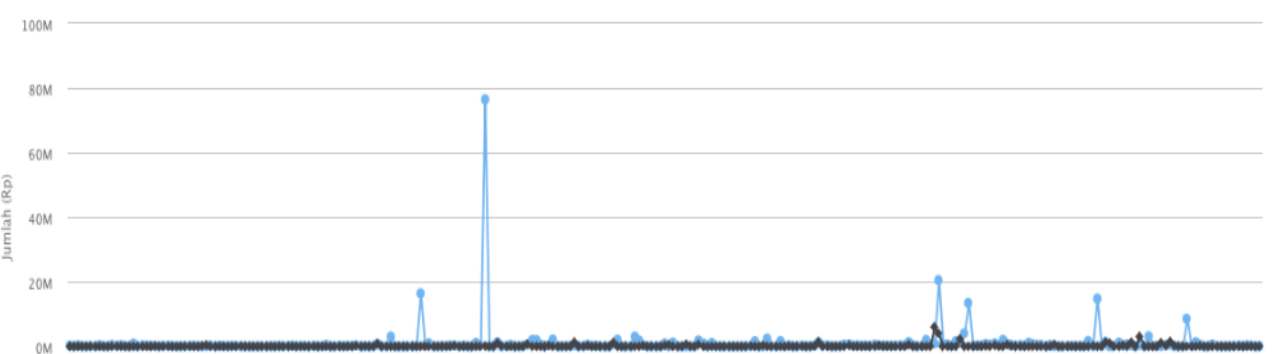

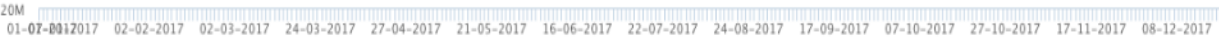

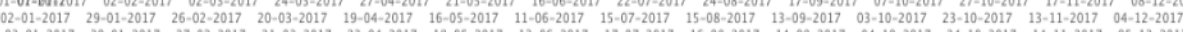

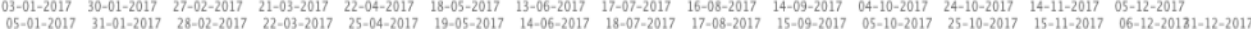

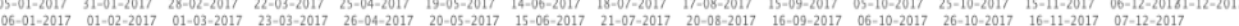

Gambar 7.

Transaksi Saldo Tahun 2017 


\section{SIMPULAN}

Hasil penelitian ini menunjukan bahwa penggunaan sistem manajemen sampah berbasis online belum optimal dikarenakan sistem online belum mengakomodasi aktivitas dan penyelesaian masalah yang dihadapi Bank Sampah. Beberapa kendala yang dihadapi diantaranya tidak tersedianya cukup informasi mengenai kategori sampah, tenaga penjemput sampah tidak selalu tersedia, aktivitas pencatatan berulang pada rekap saldo nasabah (buku induk tabungan dan pencatatan pada komputer) dan nasabah harus menghitung secara manual saldo mereka. Selain itu, kendala lainnya yang dihadapi yaitu harga sampahyang bergantung pada penawaran pengepul serta keterbatasan tenaga pengolah sampah dan akses komunitas pengolah sampah merupakan masalah utama yang dihadapi oleh Bank Sampah.

Selain itu, pada sistem manajemen sampah berbasis onlineterdapat beberapa fitur yang dibutuhkan Bank Sampah namun penggunaannya masih terbatas dikarenakan penerimaan teknologi dari pengurus Bank Sampah yang masih tergolong rendah. Beberapa fitur yang belum digunakan dengan optimal diantaranya fitur layanan jemput sampah, informasi kategori sampah beserta harga, serta pengambilan saldo rekening bank sampah melalui ATM. Untuk penelitian lanjutan mengenai penggunaan sistem manajemen sampah berbasis online, sebaiknya dilakukan penelitian mengenai model adopsi sistem informasi berbasis online untuk menunjang kesuksesan implementasi sistem manajemen sampah berbasis online pada Bank Sampah.

\section{DAFTAR PUSTAKA}

Indrianti, N. (2016). Community-based Solid Waste Bank Model for Sustainable Education. 6th International Research Symposium in Service Management (ss. 158-166). Kuching: Procedia - Social and Behavioral Sciences.

Wijayanti, D.;\& Suryani, S. (2015). Waste Bank as Communitybased Environmental Governance: A Lesson Learned from Surabaya. 5th Arte Polis International Conference and Workshop (ss. 171-179). Bandung: Procedia - Social and Behavioral Sciences.

Singhirunnusorn, W.;Donlakorn, K.;\& Kaewhanin, W. (2012). Contextual Factors Influencing Household Recycling Behaviours: A Case of Waste Bank Project in Mahasarakham Municipality. ASEAN Conference on Environment-Behaviour Studies (ss. 688-697). Bandung: Procedia - Social and Behavioral Sciences.

Kusmargana, J. (24. Januari 2018). Bank Sampah Gemah Ripah Bantul Jadi Percontohan, Ini Kiatnya. Noudettu osoitteesta Cendana News:

http://www.cendananews.com

Sidik, H. (23. Agustus 2016). 10 Bank Sampah di Bantul tidak aktif. Noudettu osoitteesta Antara News: http://jogja.antaranews.com/

Rusqiyati, E. (6. Maret 2018). Bank Sampah Induk Yogyakarta 
kekurangan nasabah. Noudettu osoitteesta Antara News: http://jogja.antaranews.com

Ibrahim, M.;\& Nanis, M. (2016). Towards Sustainable Management of Solid Waste in Egypt. Procedia Environmental Sciences, 336-347.

Sahwan, F. (2004). Strategi Pengelolaan Sampah di Kepulauan Seribu. Balai Pengkajian dan Penerapan Teknologi, 12-16.

Murdiman;Mahendra, M.;\& Adhika, I. (2017). Pola Persepsi dan Partisipasi Masyarakat terhadap Pengelolaan Sampah Rumah Tangga dan Bank Sampah di Kecamatan Denpasar Timur Provinsi Bali. Ecotrophic, 94100.
Soni, A.;Patil, D.;\& Argade, K. (2016). Municipal Solid Waste Management. Procedia Environmental Sciences, 119126.

Sudibyo, H.;Pradana, Y.;Budiman, A.;\& Budhijanto, W. (2017). Municipal Solid Waste Management in Indonesia - A Study about Selection of Proper Solid Waste Reduction Method in D.I. Yogyakarta Province. Energy Procedia, 494-499.

Asteria, D.;\& Heruman, H. (2016). Bank Sampah sebagai Alternatif Strategi Pengelolaan Sampah Berbasis Masyarakat di Tasikmalaya. Jurnal Manusia dan Lingkungan, 136-141. 